\title{
SOCIETY'S DIVERSITY IN INFLUENCING EDUCATION (KUDUS TOWER CASE STUDY IN INFLUENCING ISLAMIC EDUCATION)
}

\author{
Muhammad Arief Nugroho \\ Institut Agama Islam Negeri Kudus, Indonesia \\ Email: ariefnugroho917@gmail.com \\ Ashif Az Zafi \\ Institut Agama Islam Negeri Kudus, Indonesia \\ Email: ashifazzafi@iainkudus.ac.id
}

\begin{abstract}
The purpose of this article is to find out how Islamic education in the area around the Kudus Tower is influenced religious community, as well as to find out the influence in Islamic education. The process of compiling this study used a qualitative approach. The data collection was done by conducting a literature study. It is known that the influence of a religious community for Islamic education in the area around the Kudus tower includes making students more familiar with Islam, as well as the special attitude of Islamic education institutions in educating their students. The results obtained from this study are Islamic educational institutions around the Kudus tower are growing rapidly and these educational institutions form students who excel in academics and have noble character. The main factor in the formation of the noble character of students is caused by the kiai who become teachers in educational institutions, a religious community environment, upholding the teachings of Islam and also side by side with the tomb of Sunan Kudus which is its own value.
\end{abstract}

Keywords: Diversity, Islamic Education, Kudus Tower.

\section{Introduction}

Indonesia is a pluralistic country, meaning that the Indonesian people are different, both from ethnicity, culture, and religion are not the same as one another. From the western end (Sabang) to the eastern end (Merauke) there are more than 1,128 ethnic groups living with their respective customs and culture). ${ }^{1}$ The number of ethnic groups, races and religions in Indonesia cannot be denied that many conflicts have occurred. However, Pancasila has taught how to tolerate diversity in society, so that a community does not fight and respect each other's differences. That is the core point of the meaning of Pancasila about diversity which has not been widely

${ }^{1}$ Widiastuti, “Analisis SWOT Keragaman Budaya Indonesia," Jurnal Ilmiah Widya, vol 1, no. 1 (2013): 10. 
absorbed, let alone implemented by each individual Indonesian citizen in his daily life. Pluralism is not just living side by side without caring about other people. It requires real bonding, cooperation, and work. The deepest bonds of commitment and the most fundamental differences in creating a community together are the main elements of pluralism. ${ }^{2}$

Indonesian society which is classified as plural or can also be called plural, has a very strong energy as cultural and social capital, namely the diversity of beliefs, religions, customs, and different languages which will bind community groups to unite against the invaders. The strong desire to unite in achieving common goals is based on the diversity of the Indonesian nation itself. It is necessary to see the diversity of Indonesian society as something fluid that aims to be just, prosperous and dignified for every citizen. Here means there are situational and contextual needs that must be updated from time to time. ${ }^{3}$ The effect of upholding diversity will establish close relationships between groups, regardless of what or who. Life will be peaceful without being based on hostility, so that the Indonesian people will be far more peaceful than when commotion arises that cause harm to themselves and others.

Education is one of the capital to achieve prosperity, there is deviant behavior due to a lack of education for a child, especially adolescents who are highly recommended to get proper education for themselves. One of the most important factors for society is getting education, whether or not the quality of the community depends on the education received by people in a country. Harahap and Perkatja argue that education is an effort that is consciously or deliberately by parents so that moral responsibility arises from all the actions of the child. ${ }^{4}$

Prophet Muhammad SAW brought Islam to teach his people to have a balanced attitude. Balanced in the sense of paying attention to the needs of life in the world and the needs of life in the hereafter, not forgetting the past even though its

${ }^{2}$ Nurhafid Ishari, "Pluralisme Agama di Sekolah; Studi Implementasi Kurikulum 2013 pada Mata Pelajaran Pendidikan Islam di Sekolah Menengah”. Tarbiyatuna: Jumal Pendidikan Islam, vol. 9, no. 2, 2016. 198.

3 D. B. Arif, "Kompetensi Kewarganegaraan untuk Pengembangan Masyarakat Multikultural Indonesia". Acta Civicus: Jurnal Pendidikan Kewarganegaraan, Vol. 1, no. 3, 2008.

${ }^{4}$ Muhibbin Syah. Psikologi Pendidikan dengan Pendekatan Baru (Bandung: PT. Remaja Rosdakarya, 2007)

124 | Tarbiyatuna: Jurnal Pendidikan Islam; Volume 14, Nomor 2, Agustus 2021 
orientation is to the future, an orientation that is open, quality and accepts everyone's opinion other by selectively agreeing with the al-Qur'an and Hadith, planning work based on the results of creative, innovative, modern research, accepting every change, upholding the attitude of brotherhood, friendship with other human beings. ${ }^{5}$

Several previous research studies that are relevant to this study as a basic reference material include first; research conducted by Muhammad Miftah with the title "Multicultural Education In The Diversity Of National Cultures" in 2016. From this research, the aim is to determine the importance of tolerance and respect every diversity that exists in the multicultural education community. In contrast to this research, which is more focused on Islam, which is the target. ${ }^{6}$

Second; Another research study is a study conducted by Raihani, et al. With the title "Delivering Islamic Studies And Teaching Diversity In Southern Thai Islamic Schools" in 2016. This research focuses more on the teaching process of Islamic studies in local Islamic schools and opportunities in the promotion of cultural and religious diversity. This study also seeks to determine possible opportunities for Islamic religious teachers and their students to learn from each other from the reality of diversity in society. Almost the same as this study, it's just that in the discussion the author does not include all the diversity of religions that exist. $^{7}$

Third; a research study conducted by M. Amin Abdullah with the title "Islam As A Cultural Capital In Indonesia And The Malay Word: A Convergence Of Islamic Studies, Social Sciences And Humanities" in 2017. This study discusses the intellectual contribution of Indonesian Muslims as an integral part of Malay for the development of Islam in Southeast Asia, and its contribution to framing moderate Muslims who support diversity, inclusion, openness, peace and harmony in a

\footnotetext{
${ }^{5}$ Abudin Nata, Ilmu Pendidikan Islam, ed. Kharisma Putra Utama Jeffry, 1st ed. (Jakarta, 2010), 34.

${ }^{6}$ Muhammad Miftah, "Multicultural Education in the Diversity of National Cultures," QIJIS (Qudus International Journal of Islamic Studies), vol. 4, no. 2 (2016).

${ }^{7}$ Raihani et al., "Delivering Islamic Studies and Teaching Diversity in Southern Thai Islamic Schools," Al-Jami'ah, vol. 54, no. 1 (2016). 
globalized world. The difference from this study lies in the focus of the issues being discussed. ${ }^{8}$

Fourth; the article written by Syamsul Arifin et al. With the title "Minority Muslims and freedom of Religion: learning from Australian Muslims' experiences" in 2019, this article explained that under the protection of the secular state (Australia), the conditions for the development of the ummah are going well. Minority Muslims living in a multicultural society can enjoy religious freedom. The existing practices of tolerance are stronger than the tensions and inter-religious conflicts that occur. ${ }^{9}$

Fifth; an article compiled by M. Solehuddin and Nandang Budiman with the title "Multicultural Competence of Prospective Preschool Teachers In Predominantly Muslim Country" in 2019, this article was written to prepare a teacher in teaching children who come from multi-ethnic and religious communities such as in Indonesia, prospective PAUD teachers need to have adequate understanding and experience on social justice and multiculturalism issues. This research resulted in the design of a multicultural competency development training model for prospective PAUD teachers which includes systematic reflection, Socratic dialogue, simulation, field practice, and reflection. ${ }^{10}$

Sixth; an article compiled by Khoirun Niam with the title "Between Unity and Diversity Resketching the Relations between Institutional-Affiliated Indonesian Muslim Intellectuals and the Government (1990-2001)" in 2020. This study found that pluralism is a sociological understanding that can be used to describe the intellectual diversity of Indonesian Muslims, which sometimes leads them, both with and without institutional associations, into various difficulties to unite. ${ }^{11}$

Seventh; an article written by Rosdalina Bukido, Ubed Abdillah Syarif, Rahman Mantu with the title Ru'yat al-aqallīyāt al-muslimah Hawla al-tadayyun: Mawqif jayl

\footnotetext{
${ }^{8}$ M. Amin Abdullah, "Islam as a Cultural Capital in Indonesia and the Malay World: A Convergence of Islamic Studies, Social Sciences and Humanities," Journal of Indonesian Islam, vol. 11, no. 2 (2017).

${ }^{9}$ Syamsul Arifin et al, "Minority Muslims and freedom of Religion: Learning from Australian Muslims Experiences," Indonesian Journal of Islam and Muslim Societies, vol. 9, no.2 (2019).

10 M. Solehuddin and Nandang Budiman, "Multicultural Competence of Prospective Preschool Teachers in Predominantly Muslim Country," Cakrawala Pendidikan, vol. 38, no. 3 (2019).

${ }^{11}$ Khoirun Niam, "Between Unity and Diversity Resketching the Relation Between InstitutionalAffiliated Indonesian Muslim Intellectuals and the Government (1990-2001)," Journal Of Indonesian Islam, vol. 14, no. 2 (2020). 
al-shabāb ë Manado in 2020. In this article it is found that the attitudes and behavior of young Muslims in Manado towards religion have a tendency towards being conservative with a scriptural and puritanical style. ${ }^{12}$

From the seventh research studies above, they have something in common, namely that they all research the diversity of society in religion. However, what distinguishes it from the previous study is more of a learning nature to accept the existing diversity. In contrast to this research study, the researcher wants to know how the influence of the diversity of society, especially the Kudus tower area for Islamic education in the vicinity. This research will discuss about Islamic education in the area around the Kudus tower which is influenced by religious communities, as well as to determine the effect or impact that occurred.

In writing the article, the author uses a qualitative type of analysis research method. Analysis is reducing, adding, combining, and matching the collected data into an article discussion. This research uses the literature study method. Literature study uses references that have relevance or relevance to the research carried out, this is done to obtain library sources, both in the form of books and journals as sources in this research.

\section{Diversity}

Diversity is the difference from various fields in society which includes ideology, religion, ethnicity and culture or more often referred to as a plural society. Religious and cultural diversity can be expressed as religious and cultural pluralism. ${ }^{13}$ Diversity in society is a situation that shows quite a lot of differences among the types in a society. ${ }^{14}$ Diversity in society cannot be avoided by every individual human being. Diversity includes race, ethnicity, nation, and even religion as sunnatullah that must be accepted. Given the many diversities in life, the attitude that needs to be developed in order to maintain social harmony is to respect the differences that exist

\footnotetext{
${ }^{12}$ Rosdalina Bukido, Ubed Abdillah Syarif, Rahman Mantu. "Ru'yat al-aqallìyāt al muslimah hawla altadayyun: Mawqif jayl al-shabāb ë Manado," Studia Islamika, vol. 27, no. 3 (2020).

13 Marzuki, Miftahuddin, Mukhamad Murdiono. "Multicultural Education in Salaf Pesantren and Prevention of Religious Radicalism in Indonesia," Cakrawala Pendidikan, vol. 39, no.1 (2020), 20.

${ }^{14}$ Nur Kholifatul Ummah and Lilik Uzlifatul Jannah, Pengembangan Potensi Keberagaman Budaya dan UMKM Desa Pancasila Melahi Pendidikan Generasi Muda, pt, 2020, 21. 
as a plurality. This kind of attitude is certainly not a serious problem when the differences involve profane matters. ${ }^{15}$

Following are the benefits and objectives of being safe according to Nur Kholifatul Ummah and Lilik Uzlifatul Jannah;

Benefits of diversity

1. Fostering an attitude of nationalism.

2. Becoming the country's identity in the eyes of the world.

3. Can be a tool to unite the nation.

4. Cultivate an attitude of tolerance.

5. The source of knowledge for the world.

Diversity goals

1. Give lessons to human in order to respect each other's beliefs and appreciate them.

2. Fostering a sense of tolerance so that the environment around is safe, comfortable, and peaceful.

\section{Islamic Education}

Education, from the point of etymology comes from the English language education which means education, while the Latin word is educatum, the word " $e$ " means a process of development from the inside out, then the word "duco" contains a developing meaning. It can be concluded that education is a human process in order to develop their abilities and expertise individually on an individual basis. Whereas education in terminology is a process or human stages in changing attitudes, ethics and behavior of individuals and groups of people to improve their mindset through teaching, training and educational actions. ${ }^{16}$

Education is a process for developing general human knowledge including developing mastery of theory and skills, making decisions and finding solutions to problems related to activities in achieving goals and solving problems in the world of

15 Ahmad Zaenuri, "Pluralisme Agama dalam Timbangan Al-Qur'an dan Sunnah serta Implementasinya dalam Dunia Pendidikan". Hermeneia: Jurnal Kajian Islam Interdisipliner. Vol. 13, No. 2. 2013.

${ }^{16}$ Nur Kholifatul Ummah, Pengembangan Potensi, 34.

128 | Tarbiyatuna: Jurnal Pendidikan Islam; Volume 14, Nomor 2, Agustus 2021 p-ISSN: 2085-6539; e-ISSN: 2242-4579; 123-140 
education or in everyday life. ${ }^{17}$ Education is very important for our lives, humans deserve and expect to always develop with the education they have. Generally, education means a life process in self-development for each individual to be able to live and carry on his life. We get education starting from the family, school and community environment. The existence of education will accompany the welfare of the next life.

Islam is a revelatory religion that has the core of tauhid or the Oneness of Allah SWT which was revealed by Allah to the Prophet Muhammad SAW as His last messenger and applies to all mankind, wherever and whenever, whose teachings cover all aspects of human life. Apart from carrying out the mission as carried by the Prophets, Islam is also a religion whose teachings are more complete and perfect than the religion brought by the previous Prophets. The religion of Islam that was brought by the Prophet Muhammad SAW is a religion that has included all the teachings brought by the previous Prophets, by first being adapted to the needs of the times. The Islamic religion brought by the Prophet Muhammad SAW is essentially for human needs, namely to maintain the soul, religion, mind, property, and human descent. ${ }^{18}$ In essence, Islam is the religion of Allah brought by the Prophets and His messengers from Prophet Adam AS to Prophet Muhammad SAW. According to the al-Qur'an, all religions that were passed down to the Prophet and the Apostles before the Prophet Muhammad are in essence the religion of Islam and its adherents are called Muslims. ${ }^{19}$

Abuddin Nata in his book explains several meanings in terms of language about Islamic education, those are;

1. Al-Tarbiyah

The word tarbiyah comes from the word rabbaa yurabbi tarbiyatan which has added meaning (zad) and develops (mimu). Tarbiyah can be interpreted as a process of growing and developing the students potential, such as physical,

17 Benny Heldrianto. 2013. Penyebab Rendahnya Tingkat Pendidikan Anak Putus Program Sekolah dalam Wajib Belajar 9 Tahun Desa Sungai Kakap Kecamatan Sungai Kakap Kabupaten Kubu Raya. http://jurmafis.untan.ac.id (diakses pada tanggal 28 April 2021).

18 Abudin Nata, Ilmu Pendidikan Islam, 33-34.

19 Misbahuddin Jamal, "Konsep Al-Islam dalam Al-Qur’an," Jurnal Al-Ulum. Vol. 11, No. 2, 2011. 292. 
intellectual, social, aesthetic and spiritual. So that students can grow and develop optimally, by means of maintaining, nurturing, caring for, repairing, and managing them in a planned, systematic and sustainable manner.

2. Al-Ta'lim

Al-Ta'lim comes from the word 'allama yuallimu ta'liman. It can be interpreted as notification of something, advice, orders, direction, teaching, training, learning, education and work or rather an apprenticeship to learn something. The word al-talim is widely used in non-formal activities with the main aim of providing insight, knowledge and information that have cognitive characteristics. So, al-ta'lim can be interpreted as an education.

3. Al-Ta'dib

Al-ta'dib comes from the word addaba yuaddibu ta'diban which is defined as education, discipline, obedience, submission, warning or punishment. The word al-ta'dib comes from the word adab which has the meaning civilized, politeness, manners, character, akblak, moral, and ethics. In the sense of education, al-ta'dib as recognition and recognition is gradually instilled in a person about the right place of everything in the order of creation, thus leading to the recognition and recognition of God's strength and majesty. ${ }^{20}$

At the time of the Prophet, education was found and the institutions had developed such as; mosques, khan mosques, khanqa, kuttab, zawiyah, ribat, and madrasas. This one institution is a higher education institution, established to strengthen the ideology of the government. When Islam was at its peak, madrassas became center of teaching and learning in Islamic education at that time, and became centers of teaching science and technology developed by the government. ${ }^{21}$ Abuddin Nata in his book explains that Islamic education is education from all its components or aspects based on Islamic teachings. Vision, mission, objectives, processes, teaching and learning, educators, students, the relationship between educators and students,

${ }^{20}$ Abudin Nata, Ilmu Pendidikan Islam. 6-14.

${ }^{21}$ Moh Rosyid, "Diniyah Muawanatul Muslimin Sejak Era Pra-Kolonial dengan Diberlakukannya Perda Kabupaten Kudus Tentang Madin Takmiliyah,” Elementary, Vol. 3, no. 1 (2015), 70.

130 | Tarbiyatuna: Jurnal Pendidikan Islam; Volume 14, Nomor 2, Agustus 2021 p-ISSN: 2085-6539; e-ISSN: 2242-4579; 123-140 
curriculum, teaching materials, infrastructure, management, environment, and aspects or components of education are based on Islamic teachings. ${ }^{22}$

\section{Discussion}

The Kudus City seen from historically being founded by Syekh Ja'far Shodiq or well known as Sunan Kudus. Sunan Kudus and a Chinese descent named LingSeng founded the Kudus City. During Hajj, Sunan Kudus stopped at Baitul Maqdis to learn more about Islam. On his return to Kudus, he brought the Arabic inscription stone dated $956 \mathrm{H}$ to coincide with the year 1549 and until now, this inscription is installed in the mihrab of the Menara Kudus Mosque. ${ }^{23}$ The Kudus City comes from the word Al-Quds which means holy. The city which is included as one of the coastal areas of coastal culture, the Kudus community is predominantly Muslim puritan (obedient in carrying out worship). That is why Kudus well known as the city of santri, due to the strong religious activities of the community. Kudus City, especially the Kudus Kulon area, is also as one of the historical, cultural and religious tourist destinations centered at the Menara Kudus Mosque and its surrounding environment.

Even though the Kudus Islam community is known as a Muslim puritan, culturally the community is still very strong in maintaining its traditional customs, for example the dandangan tradition (a cultural tradition that welcomes the arrival of the beginning of the month of Ramadan) and the Buka Lumur tradition (a cultural tradition of replacing the mosquito net cloth of the tomb of Sunan Kudus on every 10th of Shuro or Muharram). The people of Kudus city also have a tolerant nature that has been taught by Sunan Kudus, namely by not slaughtering cows and eating their meat. This attitude is carried out to respect the residents of the city of Kudus who embrace Hinduism. According to Hindu religious beliefs, the cow is a sacred animal that is highly respected. Therefore, visitors or people who go to the city of Kudus, are very difficult and even unable to find and enjoy culinary cuisine in stalls

\footnotetext{
22 Abudin Nata, Ilmu Pendidikan Islam. 36.

${ }^{23}$ Moh Rosyid, "Kawasan Kauman Menara Kudus sebagai Cagar Budaya Islam: Catatan Terhadap Kebijakan Pemerintah Kabupaten Kudus," PURBAWIDYA: Jurnal Penelitian dan Pengembangan Arkeologi, Vol. 7, no. 1 (2018), 92.
} 
and restaurants with the main menu made of beef. Usually stalls and restaurants replace them by using the main menu made of buffalo and chicken. ${ }^{24}$

\section{The Emergence Of Islamic Education Institutions Around The Kudus Tower}

Education as a process of civilization is the essence of achieving educational goals. Ki Hajar Dewantara argued that the goal of education is for a child to become a perfect human for his life, namely the life and livelihood of humans in harmony with their nature (nature) and society. One view from that, national education aims to educate the nation's life and develop Indonesian people as a whole, namely humans who have faith and devotion to God Almighty and have noble character, have knowledge and skills, physical and spiritual health, a stable and independent personality and a sense of social and national responsibility. ${ }^{25}$

Madrasas are formal educational institutions whose Islamic sciences education centers are juxtaposed with general sciences which at the beginning of the birth of Islam are part of science that is not separated from religious knowledge or can be said to have not experienced a scientific dichotomy. ${ }^{26}$ Here we will discuss several educational institutions, more precisely madrasas in the area around Kudus Tower, including; Madrasah Qudsiyyah, Madrasah NU Tasywiquth Thullab Salafiyyah (TBS), Madrasah NU Banat, Madrasah NU Muallimat. Here's the explanation:

1. Madrasah Qudsiyyah

Madrasah Qudsiyyah includes one of the oldest madrasah in Kudus City. This madrasah was founded in 1919 AD. There are several types of education level ranging from MI, MTs, and MA. This madrasah is a religion-based educational institution that combines the national curriculum with the local curriculum. The combination of general and local subjects makes this madrasa superior in its religious field without leaving general knowledge. Santri is the

24 Eko Sugiarto and Ayu Pratiwinindya, "Masjid Menara Kudus: Refleksi Nilai Pendidikan Multikultural Pada Kebudayaan Masyarakat Pesisiran," Jurnal Imajinasi, vol. 13, no. 1 (2019), 71.

25 Lukmanul Hakim, Mahasiswa Nusantara et al., "Social Humaniora Paradigma Pendidikan Multikultural dalam Keberagaman," Social Humaniora. Vol. 3, no. 2 (2019), 61-65.

${ }^{26}$ Ahmad Zaki Yamani, Pendidikan Akblak Berbasis Salafiyah di Madrasah Aliyah Khusus Nabdlatul Ulama Tasywiq At-tullab Salafiyah Kudus (Semarang: IAIN Semarang, 2008), 49.

132 | Tarbiyatuna: Jurnal Pendidikan Islam; Volume 14, Nomor 2, Agustus 2021 p-ISSN: 2085-6539; e-ISSN: 2242-4579; 123-140 
name for all Qusdsiyyah madrasah students at every level because this madrasah dominates pesantren-based subjects.

Madrasah Qudsiyyah at the MI level has a preparatory class called the sifir class, where the teachers and students are all male. This class is intended for students aged between 4-6 years. Geographically, the sifir class is located in the vicinity of the Menara Kudus Mosque. Besides as a very religious place, the mosque environment is also adjacent to the tomb of Sunan Kudus. The mosque environment as a place of choice certainly has certain goals and objectives. The teacher who teaches at the madrasa said that he chose a place for teaching and learning around Kudus Tower with the hope that from an early age the students can know the mosque from the building and its contents. The mosque is the center of religious activities for Muslims, so it indirectly introduces students to religious activities that take place in the mosque. One day the students will see people who are doing ablution, praying. The students hear the sound of the call prayer when the dluhur prayer arrives. They will also see people who are reading the al-Qur'an and people who are perform I'tikaf worship. In addition, there are still many activities in the mosque that can be seen by students as education indirectly, because the teacher does not teach them, but it is the environment that shapes the students character. ${ }^{27}$

2. Madrasah NU Banat

This Madrasah is an Islamic education institution with a private status, which was founded in 1957 AD, more precisely on January 2, 1957 AD, by a group of Ulama and Muslim community leaders in Kudus, Central Java who put their hopes and concerns on the situation and development. in the education sector of Muslims and in the Indonesian nation, the founder was KH. Masdain Amin who is the younger brother of Hadrlatusy Syekh KH. M. Arwani Amin.

This Islamic education institution is based on Pancasila and has the principle of Ablussunnah Wal Jama'ah which aims to develop and promote

${ }^{27}$ Ihsan, "Membentuk Karakter Religius Anak Usia Dini Melalui Guru Laki-Laki (Studi Kasus di Kelas Sifir Madrasah Qudsiyyah Kudus)," ThufuLA: Jurnal Inovasi Pendidikan Guru Raudhatul Athfal, vol. 8, no. 1 (2020), 81-88. 
Indonesian citizens, especially female students in the field of education to be capable, skilled and responsible citizens of the nation, state and religion. This madrasah initially aspired to equip women of the Islamic religion to have knowledge about Islam who practice and be able to lead Muslimah to live forward together with other societies, step together to meet the demands of the times and be able to compete positively with educational institutions. others who are ready to carry out physical and non-physical development programs.

One level is Madrasah Tsanawiyah, which is located on Jl. KHR Asnawi No. 30. This Tsanawiyah madrasah has a boarding school (pondok pesantren) with a combination learning system between the national curriculum and the Islamic boarding school curriculum. This madrasah can manage management well and get very satisfying grades for students during the last 25 years. It is not surprising that this madrasa has received an award from the Ministry of Education and Culture of the Republic of Indonesia for its achievements, namely an educational institution with a high index of integrity in the administration of the National Examination with an HUN of 83.28. This madrasah can provide optimal trust to all surrounding communities, especially those from out of Kudus town, even out of the island to enroll their children in MTs NU Banat Kudus. ${ }^{28}$

3. Madrasah NU Tasywiquth Thullab Salafiyyah (TBS)

This madrasah was born in the midst of Dutch colonialism, which was 2 years after the founding of Jami'iyyah Nahdlatul Ulama, precisely on 7 Jumadil Akhirah 1347 H, which coincides with November 21, 1928 AD. Madrasah TBS is located in an environment where the community adheres to local traditions, as well as strongly adheres to the teachings of Islam, located not far from the center of dissemination of Islam by Walisongo. , namely Sheikh Ja'far Shodiq or well known as Sunan Kudus. Initially, the TBS madrasah was located in the village of Baletengah, Langgardalem, Kudus City. But then it expanded into 3 villages, namely Baletengah, Nanggungan, and Kajeksan. The three villages are still

${ }^{28}$ Subaidi Subaidi and Sutain Sutain, "Supervisi Akademik Kepala Madrasah dalam Meningkatkan Kinerja Guru pada Mts NU BANAT Kudus," Jurnal Isema: Islamic Educational Management, vol. 4, no. 2 (2019), 147-62. 
located in the same area, namely the Kota sub-district, Kudus district. The distance between the TBS madrasah and the tomb of Sunan Kudus is approximately 500 meters.

Initially, the NU TBS Madrasah was founded by 2 Ulama, namely $\mathrm{KH}$. Abdul Muhith and KH. Ahmad Hadziq. Starting with the name Tasywiquth Thullab with the acronym TB means "infatuated with the students", then in 1935 AD, a young scholar who graduated from the Saudi Arabian college, KH. Abdul Jalil added the name Tasywiquth Thullab so that become Tasywiqut Thullab School. And in 1982 AD, the word school at the end of the madrasa's name was replaced by the word Salafiyyah by KH. Turaichan Adjhuri. Madrasah TBS aims to equip students to learn about religion and general knowledge and be able to practice it, be able to read and understand the yellow book, apply the knowledge they already have in their daily life, have the skills to live in society, be able to communicate using Arabic or England, can understand the knowledge needed to proceed to Islamic boarding schools and universities at home and abroad. ${ }^{29}$

4. Madrasah NU Muallimat

This madrasah was founded as a response to the development and dynamics of life. It was established on 1 Muharram $1375 \mathrm{H}$, which coincided with 20 August 1955 AD. Located on Jl. KH A Wahid Hasyim No, 4 Kudus, madrasah Muallimat is specifically for women, where in the ancient tradition women were placed in a disadvantageous position, namely as a konco wingking, so that is why in Kudus there is the term wanita pimgitan. Such a phenomenon has led to the idea of the Ulama community which was pioneered by Mr. Masyhud to elevate the dignity of the life of women in serving religion, society and the State. On July 7, 1980 AD the Aliyah level NU Mualimat Madrasah underwent a very impressive development at that time, it even became a top priority for women in Kudus city, especially those with middle and upper economies, even beating public schools in Kudus. ${ }^{30}$

${ }^{29}$ Yamani, Pendidikan Akblaq, 43-46.

${ }^{30}$ Ida Mawarti, Implementasi Strategi Pembelajaran Artikulasi pada Mata Pelajaran Sejarab Kebudayaan Islam di MA Mu'allimat NU Kudus. (Kudus: IAIN Kudus, 2019), 39-40. 


\section{Religious Society}

Society is a group of people who are closely knit because of a certain system, traditions, conventions and laws that are the same, and lead to a collective life. It should be emphasized that collective life does not necessarily mean that a group of people must live side by side in a certain area, take advantage of the same climate, and consume the same food. Trees in a garden live side by side, use the same climate, and consume the same food. Likewise, herds of deer eating grass together and moving together. But neither the trees nor the herd of deer live collectively nor build a society. In essence, society is in accordance with the scenario of the creation of humans as caliph on earth, namely the upholding of divine justice that applies to nature and humans. ${ }^{31}$

The Islamic community of Kudus City is a devout Muslim in carrying out worship or the term "Islam puritan". Residents of the community around the Kudus Tower area carry out worship and other Islamic studies at the Menara Kudus Mosque as the main place. It can be seen that people really pay attention to their religion in order to continue their life in the world. Religion is important for humans because it affects every individual and the social relationships that occur between religious humans. The most significant influence of religion for humans is related to the development of their social identity. The better the deepening of one's religion, the better the social relations that arise and the better one's behavior in society. This is because religion is a guideline for behavior. ${ }^{32}$

With the existence of a religious community, it has an impact on education around the Kudus Tower area which pays great attention to students so that they can become human resources (human resources) who know and implement religious knowledge, of course Islam has been spread by Sheikh Ja'far Shodiq in the past. In connection with the location close to the tomb of Sunan Kudus, students are more comfortable taking their Islamic education in the Kudus City, because the

\footnotetext{
${ }^{31}$ Murtadha Muthahhari, Masyarakat dan Sejarah (Yogyakarta: Rausyan fikr Institute, 2012), 5-33.

32 Moh. Rifa'i, "Kajian Masyarakat Beragama Perspektif Pendekatan Sosiologis," Al-Tanzim: Jurnal Manajemen Pendidikan Islam, Vol. 2, no. 1 (2018), 32.

136 | Tarbiyatuna: Jurnal Pendidikan Islam; Volume 14, Nomor 2, Agustus 2021 p-ISSN: 2085-6539; e-ISSN: 2242-4579; 123-140
} 
community is supportive, in the sense that they are friendly in learning and practicing Islam properly, rahmatanlil 'aalaamiin which implies that Islam brings grace for all of nature.

Schools in Madrasah that strongly strengthen religious lessons, with the guidance of the kiai, have an effect on students becoming individuals who have strong faith, broad knowledge of the Islamic religion, and have noble character. Morals themselves do not necessarily grow by themselves, there are several factors forming the morals of students, first; customs or habits. Studying in Islamic educational institutions (with kiai) makes students familiar with "akhlak". Every day they meets the kiai and at such times, the santri are used to putting their morals forward, when they met the kiai he would kiss his hand, when he saw the kiai he would bow his head. It continues as daily activity, and from there the students morals are formed. Morals are formed through practice, habit, repeating many actions and sustainable. Second; Environment, namely the community environment that surrounds a person's life and home, educational institutions, work place, as well as things in the form of culture and advice surroundings. ${ }^{33}$

The madrasa which is located around the Kudus tower is one of the influencers on the students moral because the culture of the community around the Kudus tower is based on religion. Education in Madrasas as the successor of Islamic boarding schools is not only required to improve its quality in overcoming the development of an increasingly advanced era, it is also required to continue to preserve Islamic culture which is more directed to the realization of morality, because the formation of morality is the main goal of Islamic education. ${ }^{34}$

\section{Conclusion}

The Islamic community in Kudus City is known as a Muslim puritan (obedient in carrying out worship). For the community around Kudus Tower, the center of worship and other Islamic studies are located at the Menara Kudus Mosque. The tolerant nature taught by Sunan Kudus is still inherent in a Muslim in

33 Yamani, Pendidikan Akblaq, 22-23.

${ }^{34}$ Yamani, Pendidikan Akblaq, 42.

Tarbiyatuna: Jurnal Pendidikan Islam; Volume 14, Nomor 2, Agustus 2021| 137 p-ISSN: 2085-6539; e-ISSN: 2242-4579; 123-140 
this area. Such as the prohibition for Kudus society, especially for Muslims not to slaughter or eat beef, because it is considered a sacred animal for Hindus.

Islamic education around the Kudus Tower area is very good, including Madrasah Qudsiyyah, Madrasah NU Tasywiquth Thullab Salafiyyah (TBS), Madrasah NU Banat, and Madrasah NU Muallimat. They are advanced Madrasahs. There are also various ways of optimizing education, what has become a different spotlight from other madrasas is that the 4 Islamic education institutions specialize in education for certain genders, namely Madrasah Qudsiyyah and Madrasah TBS which only have male gender students and Madrasah Banat, Madrasah Muallimat which only inhabited by the female sex. From the explanation, it can be seen that the Madrasas around Kudus Tower apply Islamic Teaching as a reference, so education is more religious in nature.

\section{Bibliography}

Abdullah, M. Amin. "Islam as a Cultural Capital in Indonesia and the Malay World: A Convergence of Islamic Studies, Social Sciences and Humanities." Journal of Indonesian Islam 11, no. 2 (2017), 307-328.

Arif, D. B. "Kompetensi Kewarganegaraan Untuk pengembangan Masyarakat Multikultural Indonesia." Acta Civicus: Jurnal Pendidikan Kewarganegaraan. Vol. 1, No. 3 (2008), 68-74.

Arifin, Syamsul, Hasnan Bachtiar, Ahmad Nur Fuad, Tongat, Wahyudi. "Minority Muslims and freedom of religion: learning from Australian Muslims' experiences," Indonesian Journal of Islam and Muslim Societies 9, no.2 (2019), 295326.

Bukido, Rosdalina, Ubed Abdillah Syarif, Rahman Mantu. "Ru'yat al-aqallīyāt al muslimah hawla al-tadayyun: Mawqif jayl al-shabāb ë Manado," Studia Islamika 27, no. 3 (2020), 551-596.

Hakim, Lukmanul. "Social Humaniora Paradigma Pendidikan Multikultural Dalam Keragaman Social Humaniora" 3, no. 2 (2019), 61-65.

Heldrianto, Benny. 2013. Penyebab Rendahnya Tingkat Pendidikan Anak Putus Program Sekolah Dalam Wajib Belajar 9 Tahun Desa Sungai Kakap Kecamatan Sungai kakap Kabupaten Kubu Raya. http://jurmafis.untan.ac.id (diakses pada tanggal 28 April 2021).

Ihsan. "Membentuk Karakter Religius Anak Usia Dini Melalui Guru Laki-Laki (Studi Kasus Di Kelas Sifir Madrasah Qudsiyyah Kudus)." ThufuLA: Jurnal Inovasi Pendidikan Guru Raudhatul Athfal, Vol. 8, no. 1 (2020), 79-92. 
Ishari, Nurhafid. "Pluralisme Agama di Sekolah; Studi Implementasi Kurikulum 2013 Pada Mata Pelajaran Pendidikan Islam di Sekolah Menengah." Tarbiyatuna: Jurnal Pendidikan Islam. Vol. 9, No. 2 (2016), 191-207.

Jamal, Misbahuddin. "Konsep Al-Islam Dalam Al-Qur'an." Jurnal Al-Ulum. Vol. 11, No. 2 (2011), 283-310.

Marzuki, Miftahuddin, Mukhamad Murdiono. "Multicultural Education In Salaf Pesantren And Prevention Of Religious Radicalism In Indonesia," Cakrawala Pendidikan. Vol. 39, no.1 (2020), 12-25.

Mawarti, Ida. 2019. Implementasi Strategi Pembelajaran Artikulasi Pada Mata Pelajaran Sejarah Kebudayaan Islam Di MA Mu'allimat NU Kudus. Kudus: IAIN Kudus.

Miftah, Muhammad. "Multicultural Education in the Diversity of National Cultures." QIJIS (Qudus International Journal of Islamic Studies). Vol. 4, no. 2 (2016), 167185.

Muthahhari, Murtadha. 2012. Masyarakat dan Sejarah. Yogyakarta: Rausyan fikr Institute.

Nata, Abudin. 2010. Ilmu Pendidikan Islam. Edited by Kharisma Putra Utama Jeffry. 1st ed. Jakarta.

Niam, Khoirun. "Betweenn Unity and Diversity Resketching the Relation between Institutional-Affiliated Indonesian Muslim Intellectuals and the Government (1990-2001)," Journal of Indonesian Islam, Vol. 14, no. 2 (2020), 477-498.

Raihani, Promadi Karim, Sopyan M. Asyari, and Nunu Mahnun. "Delivering Islamic Studies and Teaching Diversity in Southern Thai Islamic Schools." AlJami'ah. Vol. 54, no. 1 (2016), 123-146.

Rifa'i, Moh. "Kajian Masyarakat Beragama Perspektif Pendekatan Sosiologis.” AlTanzim : Jurnal Manajemen Pendidikan Islam. Vol. 2, no. 1 (2018), 32-35.

Rosyid, Moh. "Diniyah Muawanatul Muslimin Sejak Era Pra-Kolonial Dengan Diberlakukannya Perda Kabupaten Kudus Tentang Madin Takmiliyah.” Elementary. Vol. 3, no. 1 (2015): 59-91.

Rosyid, Moh. "Kawasan Kauman Menara Kudus Sebagai Cagar Budaya Islam: Catatan Terhadap Kebijakan Pemerintah Kabupaten Kudus." PURBAWIDYA: Jurnal Penelitian Dan Pengembangan Arkeologi. Vol. 7, no. 1 (2018), 90-101.

Solehuddin, M., and Nandang Budiman. "Multicultural Competence Of Prospective Preschool Teachers In Predominantly Muslim Country," Cakrawala Pendidikan. Vol. 38, no. 3 (2019), 438-451. 
Subaidi, Sutain. "Supervisi Akademik Kepala Madrasah Dalam Meningkatkan Kinerja Guru Pada Mts Nu Banat Kudus.” Jurnal Isema : Islamic Educational Management 4, no. 2 (2019), 149-151.

Sugiarto, Eko, and Ayu Pratiwinindya. "Masjid Menara Kudus: Refleksi Nilai Pendidikan Multikultural Pada Kebudayaan Masyarakat Pesisiran." Jurnal Imajinasi. Vol. 13, no. 1 (2019), 69-76.

Syah, Muhibbin. 2007. Psikologi Pendidikan Dengan Pendekatan Baru. Bandung: Pt Remaja Rosdakarya.

Ummah, Nur Kholifatul, and Lilik Uzlifatul Jannah. 2020. Pengembangan Potensi Keberagaman Budaya Dan Umkm Desa Pancasila Melalui Pendidikan Generasi Muda. Lamongan: Litbang Pemas Unisla.

Widiastuti. “Analisis SWOT Keragaman Budaya Indonesia.” Jurnal Ilmiah Widya. Vol. 1, no. 1 (2013), 8-14.

Zaenuri, Ahmad. "Pluralisme Agama dalam Timbangan Al-Qur'an dan Sunnah serta Implementasinya dalam Dunia Pendidikan." Hermeneia: Jurnal Kajian Islam Interdisipliner. Vol. 13, No. 2 (2013), 138-154.

Zaki Yamani, Ahmad. 2008. Pendidikan Akblak Berbasis Salafiyah Di Madrasah Aliyah Khusus Nabdlatul Ulama Tasywiq At-tullab Salafiyah Kudus. Semarang: IAIN Semarang. 